\title{
Vandals force volunteer doctors to close clinic in Calais's refugee camp
}

Bringing care to thousands of refugees in northern France comes with many challenges, as Richard Hurley reports. The charity Doctors of the World is well versed in helping the most vulnerable people in both developing and developed countries, which is why we've chosen it for The BMJs winter appeal this year. Please give generously

\section{Richard Hurley features and debates editor, The BMJ}

Soon after last November's terrorist attacks in Paris, vandals broke into the clinic run by the humanitarian charity Doctors of the World (Médecins du Monde) in the heart of Calais's huge and longstanding refugee camp.

Mohammed Bakir, a senior house officer in the United Kingdom who has volunteered for Doctors of the World three times in Calais, saw the clinic before and afterwards. "No one knows who vandalised it," he told The BMJ. "It was the hub of the camp. Refugees would come and chat with us. We were not only providing medical assistance but also recognising their humanity."

Fearing for the safety of its volunteers, Doctors of the World has not reopened the clinic.

\section{Van torched}

Days later, a $€ 30000$ ( $£ 22000 ; \$ 33000$ ) van that the charity’s volunteers used for psychological consultations was torched in a garage in the city.

Bakir explained, "People were angry after the Paris attacks. We were briefed not to wear our Doctors of the World jackets on the streets of Calais and not to talk about our work."

"There are people who do not support us," concurred Jean-François Corty, a medical doctor and Doctors of the World's director for some 70 programmes in France, who visits the camps every month.

"On Facebook and Twitter my team has been targeted by extremists, threatening potential attacks to our vehicles and property.'

Refugees from war ravaged countries, including Syria, Afghanistan, South Sudan, and Eritrea, have been congregating on France's northernmost coast for more than a decade, prevented from making the final legs of their long journeys to England, where they wish to claim asylum.

\section{Emblem for mass suffering}

The camp at Calais has become an emblem for mass suffering of refugees, and today some 5000 men, women, and children live there, arriving with only the possessions that they were able to carry.

In the past three months, the number of refugees stuck in another camp at Grande-Synthe, a suburb of Dunkirk, has mushroomed from fewer than 100 to some 2500 people. The refugees include many families and around 500 children, mostly Kurds from Iran, Iraq, and Turkey.

"The situation in Calais and Dunkirk is very bad," Corty said. Despite the young population, 15 migrants died in the Calais camp between June and September 2015, he said. "There is no respect regarding minimum humanitarian standards. There is no respect for minimum vital needs."

Because people in the camps have no access to drinking water, food, and healthcare, Doctors of the World launched an emergency programme, as it would in a war context.

Last summer, it established a fixed clinic in the middle of the camp, and between June and November its volunteers provided 4000 consultations to migrants. It also operates mobile clinics.

\section{Sixth richest country doing nothing}

The charity also works to try to compel the French authorities to meet their ethical and legal obligations-for example, to provide drinking water for the camps' inhabitants.

The refugee camps are a political hot potato in France, with some commentators fearing that establishing even the most basic of services might encourage more refugees to come. This year, in the Calais camp, the authorities opened the Jules Ferry Centre to provide food for 2000 people a day and 24 hour shelter 
for 300 women and children. But it's nowhere near enough; everyone else sleeps outside.

"At the beginning the authorities were doing nothing," said Corty. "We were fed up. For the sixth richest country in the world to do nothing and let thousands of women and children sleep outside is not acceptable."

In September, a French court ruled that the authorities must provide access to clean water and identify and isolate minors, in a case brought by Doctors of the World and others.

Today, the authorities and other third sector players are starting to provide medical care in the Calais camp. Doctors of the World still operates mobile clinics for psychological consultations.

"We'll try to find a new fixed place as soon as possible," said Corty.
However, says Corty, "Today in Grande-Synthe [Dunkirk], the authorities are doing nothing. We will continue mobile clinics." Both Corty and Bakir encourage healthcare professionals who wish to volunteer to get in touch with Doctors of the World. The charity's programmes in Calais and Dunkirk cost some $€ 60$ 000 a month to run. "As an independent organisation we rely on private donations," explained Corty. "For advocacy it's essential to be independent. We are so grateful for donations."

Competing interests: I have read and understood BMJ policy on declaration of interests and have no relevant interests to declare. Provenance and peer review: Commissioned; not externally peer reviewed.

Cite this as: BMJ 2016;352:1182

๑) BMJ Publishing Group Ltd 2016 


\section{Donate to Doctors of the World}

- $£ 80$ could provide 10 psychological consultations for survivors of war

- $£ 135$ could provide an emergency backpack containing drugs and consumables used by mobile doctors to treat refugees in Greece and the Balkans

- $£ 180$ could provide 25 hygiene kits for refugees living in poor sanitary conditions throughout Europe

Donate online: www.doctorsoftheworld.org.uk/BMJ

Donate $£ 10$ by text message: text DOCTOR to 70660 (UK mobiles only)

Donate by phone: $+44(0) 2035357955$ 